by Frederik Hilgen ${ }^{1}$, Hayfaa Abdul Aziz, ${ }^{1,2}$, David Bice ${ }^{3}$, Silvia Iaccarino ${ }^{4}$, Wout Krijgsman ${ }^{2}$, Klaudia Kuiper ${ }^{1,5}$, Alessandro Montanari ${ }^{6}$, Isabella Raffi ${ }^{7}$, Elena Turco ${ }^{4}$, and Willem-Jan Zachariasse ${ }^{1}$

\title{
The Global boundary Stratotype Section and Point (GSSP) of the Tortonian Stage (Upper Miocene) at Monte Dei Corvi
}

\author{
1 Stratigraphy/Paleontology, Dept. of Earth Sciences, Utrecht University, The Netherlands (Email:fhilgen@geo.uu.nl) \\ 2 Paleomagnetic Lab. "Fort Hoofddijk", Dept. of Earth Sciences, Utrecht University, The Netherlands \\ 3 Department of Geology, Carleton College, Northfield MN 55057, USA \\ 4 Dipartimento di Scienze della Terra, Universita degli Studi di Parma, Parma, Italy \\ 5 Department of Isotope Geochemistry, Vrije Universiteit Amsterdam, The Netherlands \\ 6 Osservatorio Geologico di Coldigioco, 62020 Frontale di Apiro, Italia \\ 7 Dip. di Scienze della Terra, Univ. "G. D’Annunzio”, 66013 Chieti Scalo, Italy
}

The GSSP of the Tortonian Stage, which per definition marks the base of the Tortonian and, hence, the boundary between the Serravallian and Tortonian Stages of the Middle and Upper Miocene Subseries, has recently been defined and ratified by the IUGS. The boundary stratotype-section is Monte dei Corvi (Italy) where the Tortonian GSSP is now formally at the mid-point of the sapropel of small-scale sedimentary cycle no. 76, close to the last common occurrences (LCOs) of the calcareous nannofossil Discoaster kugleri and the planktonic foraminifer Globigerinoides subquadratus and associated with the short normal subchron C5r.2n. The GSSP level coincides closely with oxygen isotope event Mi-5 and the associated glacio-eustatic sea-level low-stand of supercycle T3.1 and concurrent deep-sea hiatus NH4, and is dated astronomically at $11.608 \mathrm{Ma}$. The Monte Gibliscemi section is accepted as an auxiliary boundary stratotype because the better preservation of the calcareous microfossils in this section enables quantitative analyses and the construction of a stable isotope record.

\section{Introduction}

The aim of this paper is to announce the ratification of the Global boundary Stratotype Section and Point (GSSP) of the Tortonian Stage. Together with the Messinian, the Tortonian represents the twofold subdivision of the Upper Miocene Subseries in the Global Standard Chronostratigraphic scale.

A brief description of the stratotype-section, the boundary and the various stratigraphic tools available for global correlation of the Tortonian GSSP is presented. Additional information is found in the original proposal (Hilgen et al., 2002) and in the literature referred to in this paper. The integrated stratigraphic data and astronomical tuning of the sedimentary cycles, which underlie the selection of Monte dei Corvi as boundary stratotype-section, are reported in detail elsewhere (Hilgen et al., 2003). The proposal (Hilgen et al., 2002) was forwarded to all SNS voting members in 2002 for postal ballot and almost unanimously accepted. Following the results of the postal ballot, a formal recommendation of SNS was submitted to the Secretary General of the ICS in spring 2003. Official acceptance by the ICS and ratification by the IUGS Executive Committee were obtained later that year.

\section{Background and motivation}

During the last years, much progress has been made in the standardization of the Neogene part of the Global Standard Chronostratigraphic scale by defining the GSSPs of all Pliocene Stages (Castradori et al., 1998; Rio et al., 1998; Van Couvering et al., 2000) and the youngest Messinian Stage of the Miocene (Hilgen et al., 2000a). The logical next step is to select and define the GSSP for the next older stage in the Miocene, the Tortonian (Mayer-Eymar, 1858). This step is greatly facilitated by the progress recently made in establishing orbital-tuned integrated stratigraphic frameworks for the Middle/Upper Miocene both in the Mediterranean (Hilgen et al., $1995,2000 \mathrm{~b}, 2003)$ and in the open ocean (Shackleton and Crowhurst, 1997; Shackleton et al., 1999).

The Tortonian has been consistently used as a global stage in almost all standard geological time scales including the most recent ones (e.g., Harland et al., 1990; Berggren et al., 1995). Nevertheless, considerable uncertainty existed about the guiding criteria and age of the base Tortonian. In addition the proven unsuitability of the historical stratotype section some $10 \mathrm{~km}$ south of Tortona necessitated the search for an alternative boundary stratotype section. Of the candidate sections, Monte dei Corvi located on the Adriatic coast of northern Italy proved to be the only section that provided a good to excellent magnetostratigraphy, calcareous plankton biostratigraphy and cyclostratigraphy in the critical interval. But before introducing Monte dei Corvi and the integrated stratigraphic data of this section, we will start with a condensed review of the history of the Tortonian stage concept.

\section{A brief historical review of the Tortonian}

Original definition of the Tortonian (Mayer-Eymar, 1858)

The Tortonian Stage ("Tortonische Stufe"), named after the town of Tortona in northern Italy, was introduced by Mayer-Eymar 

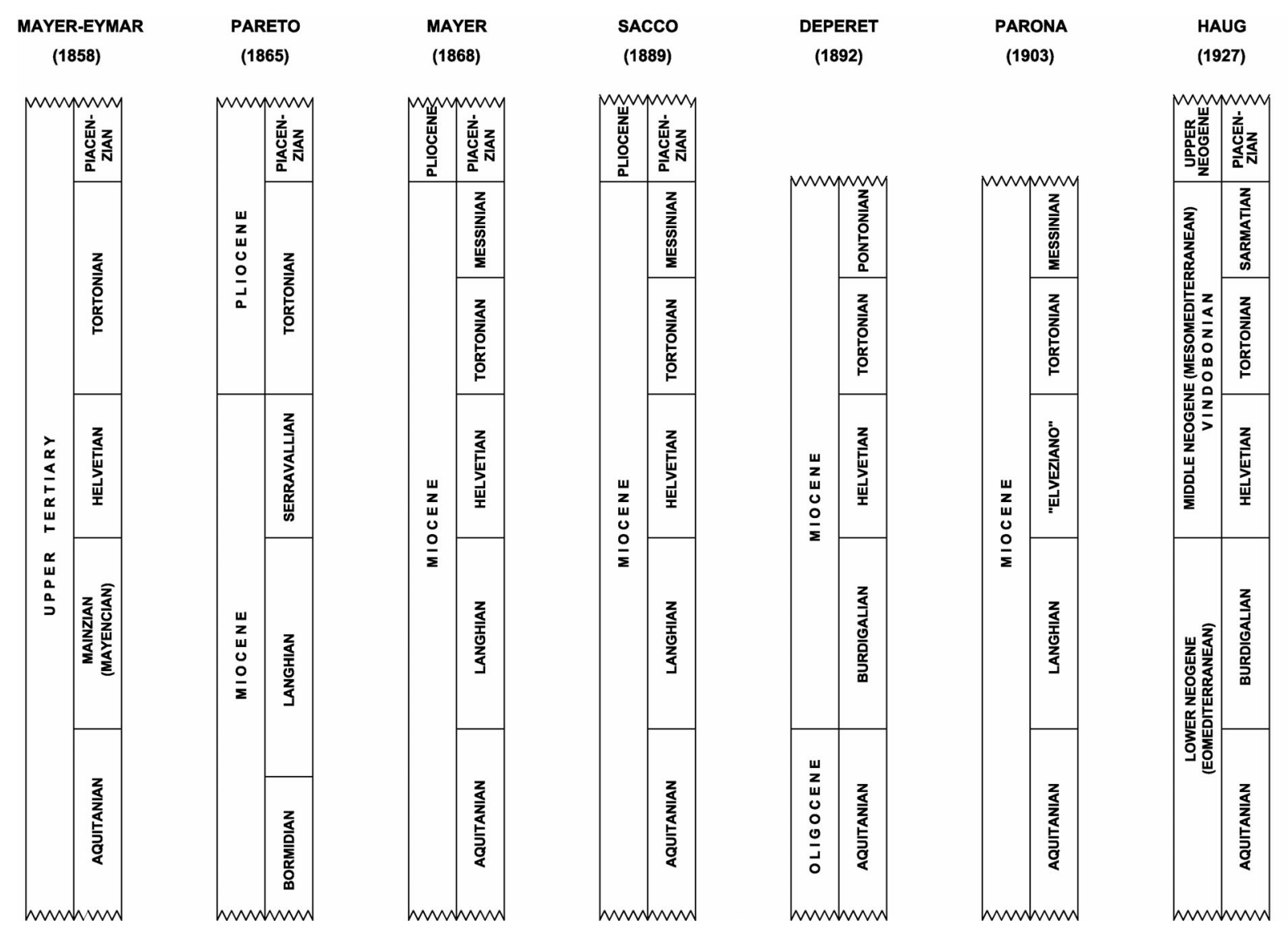

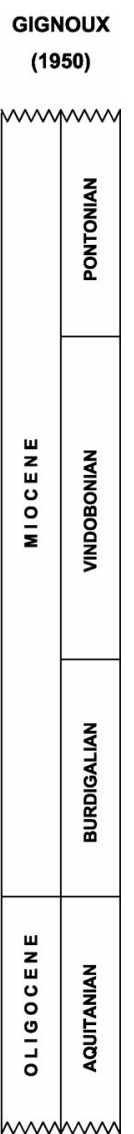

A

Figure 1 Historiacal review of the Miocene chronostratigraphic subdivision. A. chronostratigraphic proposals before the development of calcareous plankton.

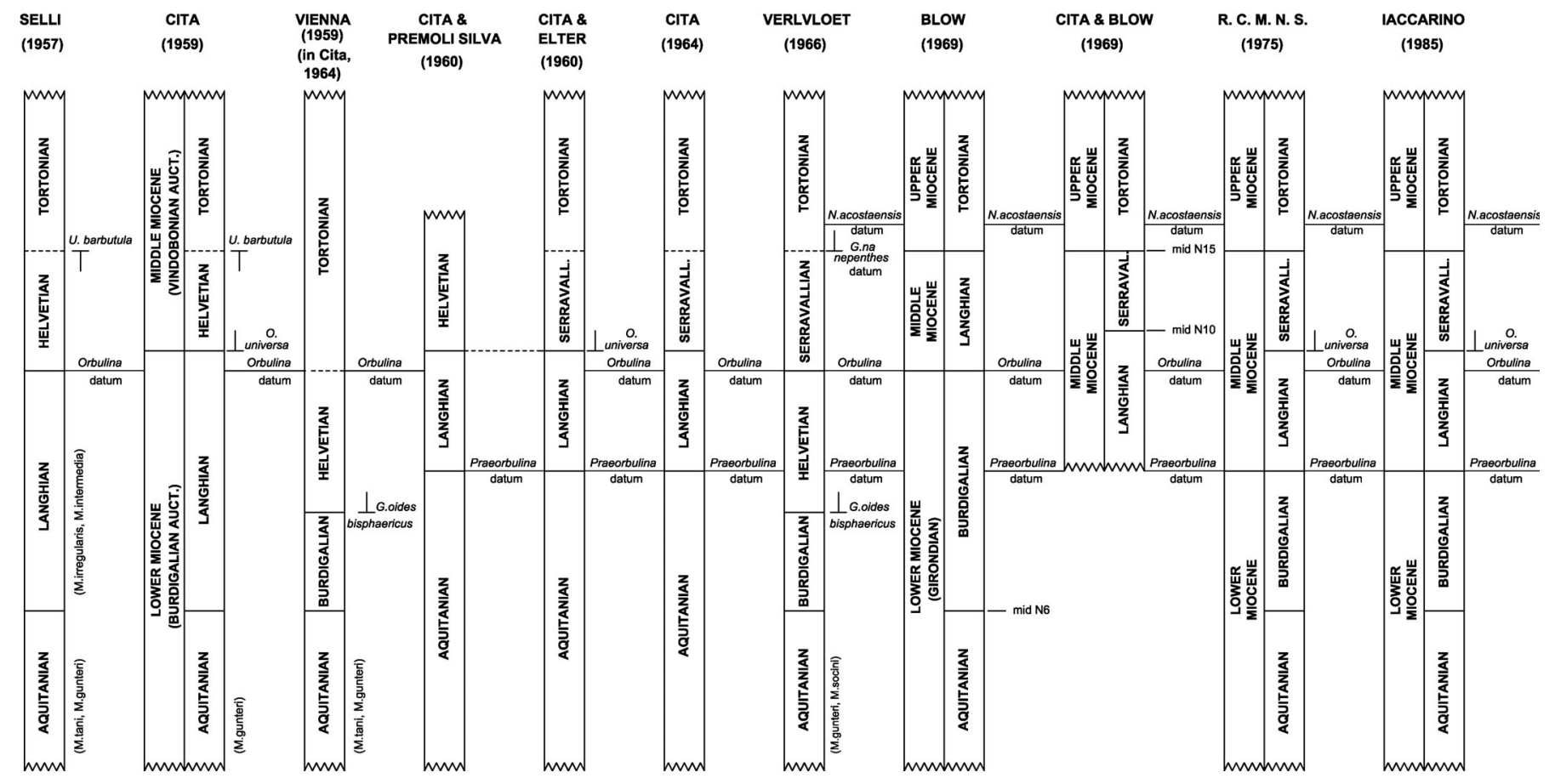

Figure 1 (continued) B. Chronostratigraphic proposals using planktonic foraminifer biostratigraphy. 

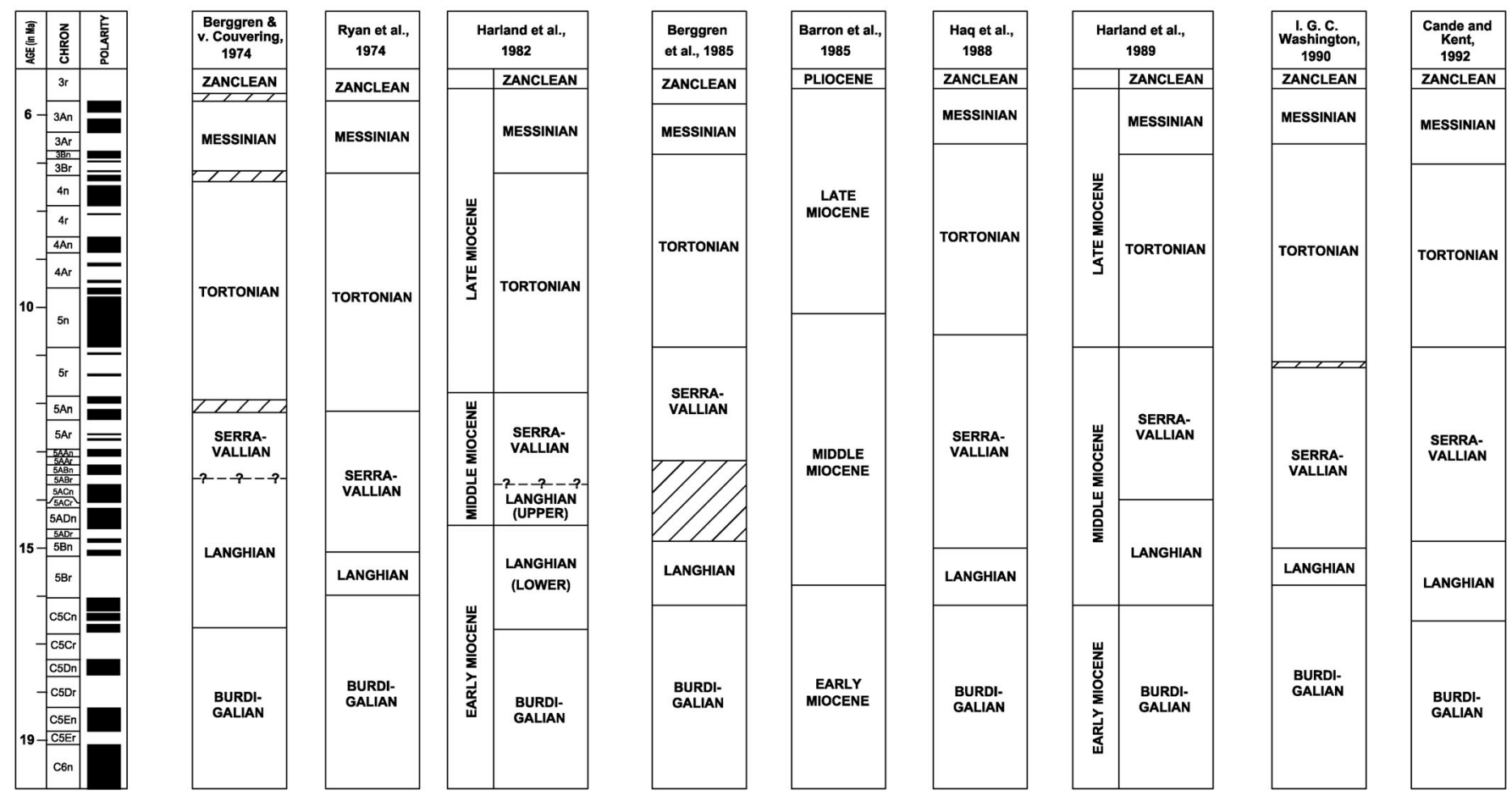

C

Figure 1 (continued) C.Position of the Miocene stages versus magnetostratigraphy in the most widely used chronostratigraphic schemes proposed between 1970 and 1995.

in 1858 as "Blaue Mergel mit Conus canaliculatus und Ancillaria glandiformis von Tortona". In his original definition of the Tortonian, Mayer-Eymar included:

-- Marine strata of Tortona (Italy), Baden (Vienna Basin) and Cabrières d'Aigues (Vaucluse, Fr.);

-- Continental beds with Hipparion at Eppelsheim; beds at Cucurou (Mont-Leberon, Vaucluse, France) and Orignac (Hautes Pyrénées, France) with the same fauna.

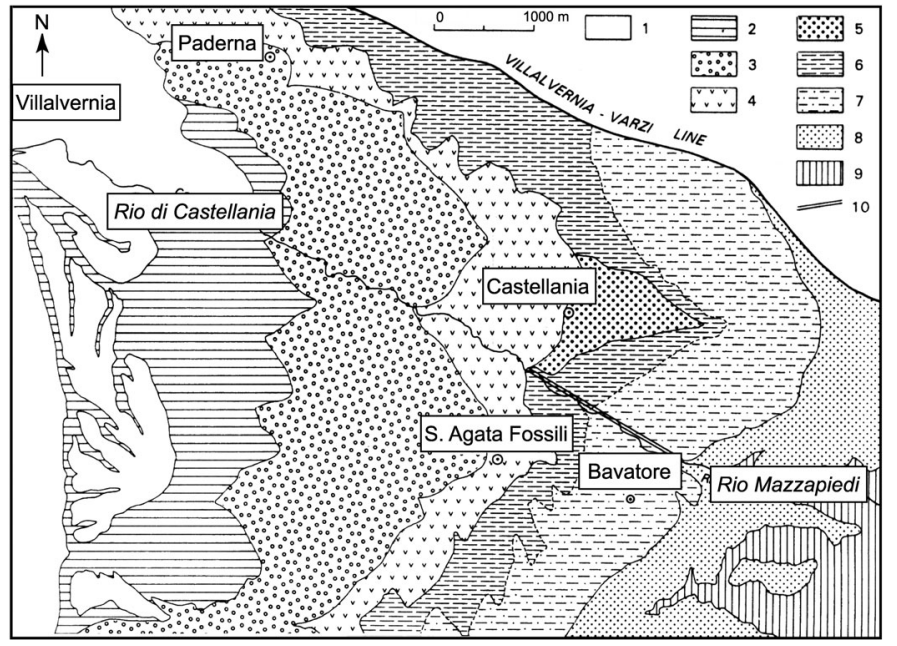

Figure 2 Geological map of the Tortonian type area and location of the Tortonian stratotype section in the valley of Rio Mazzapiedi and Rio Castellania between the villages of Sant' Agatha Fossili (after Clari and Ghibaudo, 1979). 1 = alluvial deposits; 2 = Lugagnano Clays; 3 = Cassano Spinola Conglomerate; 4 = Gessoso-Solfifera Formation; 5 = Alosio Conglomerate; $6=S$. Agata Fossili Marl (upper member); 7 = S. Agata Fossili Marl (lower member); $8=$ Serravalle Sandstone; $9=$ Apennine units; and $10=$ trace of the Tortonian stratotype section.
It is important to realise that Mayer-Eymar extended the Tortonian up to the base of the Piacenzian considered to be basal Pliocene of age (Figure 1). In 1868, he decapitated his Tortonian Stage by introducing the term Messinian to embody the regressive, brackish-water strata above the marine Tortonian (Figure 1). Despite this complex history, the term Tortonian was soon adopted after its introduction partly because of the many influential papers on the subdivision of the Tertiary published by Mayer-Eymar (Figure 1).

\section{Tortonian stratotype section (Gianotti, 1953)}

The Rio Mazzapiedi-Castellania section located between the village of Sant' Agata Fossili and the town of Alessandria, some 10 $\mathrm{km}$ south of Tortona (Figure 2), was designated as the Tortonian stratotype by Gianotti (1953) following the geological study of the type area by Gino (1953). Relevant studies in the area have subsequently been carried out by Vervloet (1966), Clari and Ghibaudo (1979) and Ghibaudo et al. (1985) to which the reader is referred for detailed information. The Tortonian stratotype mainly consists of marly sediments (the Sant' Agata Fossili marls of Ghibaudo et al., 1985), which overlie the deltaic sandstones (Mutti E., personal communication) of the Serravalle Formation (Figure 2). Clari and Ghibaudo (1979) subdivided the Sant' Agata marls into two members. The lower member is composed of a $180 \mathrm{~m}$ thick succession of bioturbated fine sandstones alternating with clayed siltstones while the upper member consists of an $80 \mathrm{~m}$ thick succession of blue-grey hemipelagic silty marls with thin turbidites in its upper part. Biota and lithofacies associations indicate an outer shelf and slope environment respectively.

The Rio Mazzapiedi-Castellania section is unanimously considered as the reference for the nominate time interval. It should be noted however that according to Gianotti (1953) the type Tortonian included the so-called "Marne tabacco a Cerizi" underlying the evaporitic sequence and yielding poor and oligotypical foraminiferal faunas. The younger end of the Tortonian of Gianotti (1953) has been decapitated later by the lowering of the Messinian base (Cita et al., 1965; d'Onofrio et al., 1975). 
The Tortonian is consistently reported as a global stage in all the geological time scales (Figure 1). In addition there existed a general consensus that the Tortonian base is approximated by the first occurrence (FO) of the planktonic foraminifer Neogloboquadrina acostaensis (see below).

\section{Timing of the base of the Tortonian and top of the Serravallian stratotype}

The Serravallian/Tortonian (S/T) boundary was commonly placed at or close to the $N$. acostaensis FO (Cita and Blow, 1969 and Rio et al., 1997 for recent references). This bioevent was first recorded by Cita et al. (1965) from the basal part of the Tortonian historical stratotype section of Rio Mazzapiedi-Castellania (Figure 3) and was coincident with the base of the G. mayeri-G. nepenthes Zone. Later Cita and Blow (1969), who considered the FO of $N$. acostaensis as the evolutionary appearance from $G$. continuosa (N15/N16 boundary of Blow, 1969), indicated that this event best approximated the base of the Tortonian. The basal part of the Tortonian was assigned to nannofossil zone NN9 on the basis of the presence of the zonal marker Discoaster hamatus (Mazzei, 1977).

These zonal assignments are conflicting, however, with the common practise to place the N15/N16 boundary at or close to the base of NN8 (see Rio et al., 1997). Recent data from the Monte Gibliscemi section (Sicily) even indicate that the $N$. acostaensis FO actually falls within zone NN7 in the Mediterranean as previously suggested by Foresi et al. (1998). This indicates that the so-called $N$. acostaensis FO at Rio Mazzapiedi-Castellania does not represent the true first occurrence of this taxon, as recently confirmed by the presence of rare $N$. acostaensis in the top part of the Serravalle Sandstones immediately below the base of the Tortonian stratotype (Miculan, 1997; Foresi et al., 1998). Evidently, the base of the Tortonian stratotype postdates the $N$. acostaensis FO.

The base of the Tortonian stratotype is older than the first regular occurrence (FRO) of $N$. acostaensis of Foresi et al. (1998). But the position of the $N$. acostaensis FRO above the D. hamatus FO in the Tortonian stratotype (Foresi et al., 1998) conflicts with findings from Monte Gibliscemi which indicate that the D. hamatus/bellus entry is delayed in the Mediterranean with respect to low latitudes and postdates the N.acostaensis FRO by several 100 kyrs (Hilgen et al., 2000b). Samples from the Tortonian stratotype studied by Foresi et al. (1998) were checked to solve this discrepancy by means of a semi-quantitative analysis and following the taxonomic criteria outlined by Hilgen et al. (2000b), the

$N$. acostaensis FRO is positioned lower in the succession near the base of the Tortonian and below the D. hamatus FO. Moreover, the dominant right coiling of the neogloboquadrinids from the lower part of the Tortonian and the underlying Serravalle sandstones indicates that there is not a discernable hiatus at the base of the Tortonian stratotype and that the top part of the Serravalle sandstones postdates the first influx of the neogloboquadrinids at Monte Gibliscemi in which the coiling direction is essentially random. These findings further imply that the base of the type Tortonian postdates the last occurrence (LO) of Paragloborotalia mayeri (P. siakensis of Foresi et al., 1998) and, as a consequence, that all reported occurrences of this taxon in the Tortonian stratotype should be considered reworked. In conclusion, the Tortonian base in the historical strato-

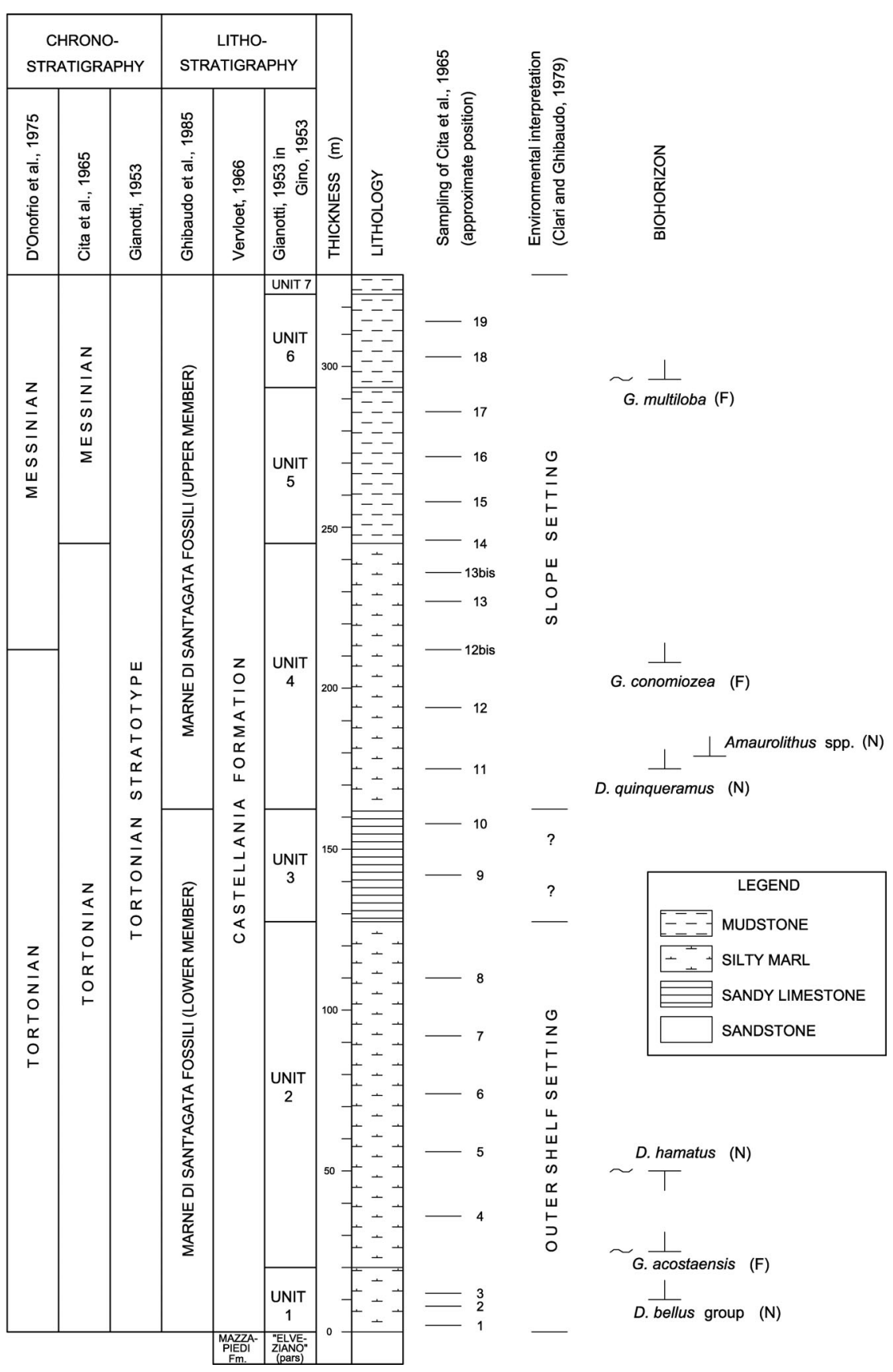

Figure 3 Summary of the calcareous plankton biostratigraphic data from the Tortonian stratotype (from Rio et al., 1997). $F=$ Planktonic foraminifer, $N=$ Calcareous nannofossil. The most recent data have not been included (see text).

type corresponds almost exactly with the $N$. acostaensis FRO as defined at Monte Gibliscemi and dated astronomically at $10.554 \mathrm{Ma}$ (see Hilgen et al., 2000b). This observation is more or less consistent with Müller (1975) who examined the "Serravallian of the Rio Mazzapiedi section" and referred it with certainty to NN7, and probably also to NN8 and the lower part of NN9 (reported only in the abstract of the paper) although the latter could not be confirmed due to the lack of samples from the uppermost part of the Serravalle sandstones in this section.

The top of the Serravallian stratotype in the Serravalle Scrivia section can be dated at $11.8 \mathrm{Ma}$ by linear extrapolation of the sedimentation rate between the Sphenolithus heteromorphus LO (13.5 $\mathrm{Ma}$; Rio et al., 1997) and the last common occurrence (LCO) of Calcidiscus premacintyrei (12.3 Ma; Rio et al., 1997). This admittedly 
rough age estimate indicates that there is no overlap in time between the top of the Serravallian stratotype and the base of the Tortonian stratotype and that all bioevents in the interval between 11.8 and $10.554 \mathrm{Ma}$ are potentially suitable for delimiting the S/T boundary.

\section{Selecting the most suitable section and level for defining the Tortonian GSSP}

In the Neogene, orbital tuned cyclostratigraphies (Hilgen et al., 1995, 2000a; Lourens et al., 1996) play an important role in addition to conventional criteria outlined by the International Commission on Stratigraphy (ICS) in the revised guidelines for establishing global chronostratigraphic standards (Remane et al., 1996). This extra criterion is added here because all ratified Neogene GSSPs are defined at lithological marker beds that are astronomically dated. In this way they are tied via first-order calibrations to the standard geological time scale once this time scale is underlain by astronomical tuning as is already the case for the Plio-Pleistocene (Berggren et al., 1995). This implies that other requirements being equal cyclostratigraphy will play a critical role in selecting the most suitable section and level for defining the Tortonian GSSP.

\section{Selecting the guiding criterion for defining the boundary}

According to the available biostratigraphic data from the historical stratotype sections (Serravallian and Tortonian), the Tortonian GSSP should be defined somewhere in the interval between the $\mathrm{Cal}$ cidiscus praemacintyrei $\mathrm{LCO}$ (= top Serravallian type section, Rio et al., 1997) and the Neogloboquadrina acostaensis FRO (= base Tortonian type section, Hilgen et al., 2000b). Three different options were considered for locating the boundary by the Working Group on the Tortonian GSSP:

1) to place the boundary coincident with the FRO of $N$. acostaensis dated astronomically at $10.544 \mathrm{Ma}$ in the Monte Gibliscemi section. The boundary would closely coincide with the base of the Tortonian in the historical stratotype section and approximately with a major turnover in the calcareous nannofossils marked by the appearance of five-rayed discoasters (Discoaster bellus group) in the low latitudes;

2) to place the boundary at or close to the base of the long normal interval of C $5 n .2 n$. This reversal has been dated astronomically at 11.043 Ma in the continental section of Orera in Spain (Abdul Aziz et al., 2003). In the open ocean the boundary would be approximated by the Coccolithus miopelagicus LCO and the Catinaster coalitus $\mathrm{FO}$; and

3) to place the boundary at or close to the Discoaster kugleri and Globigerinoides subquadratus LCOs dated at 11.604 and 11.539 Ma in the Monte Gibliscemi section (Hilgen et al., 2000b). These events have similar ages in the Case Pelacani and Tremiti Islands sections (Caruso et al., 2002; Lirer et al., 2002).

The first option is regarded less favourable in view of the relatively low global correlation potential even though the boundary would in that case coincide closely with the Tortonian base in the historical stratotype. The second option was seriously taken into consideration also because it would result in a duration of the Tortonian that deviates less from that of the next younger Messinian stage and, probably, the older Serravallian stage. But this option has not been adopted because calcareous plankton events close to the boundary are considered less suitable for global recognition of the boundary. The $C$. miopelagicus $\mathrm{LCO}$ is diachronous while $C$. coalitus is a less reliable marker in the Mediterranean and its presence/absence in the open ocean is environmentally controlled.

The third option was preferred because of the high correlation potential using multiple stratigraphic tools (planktonic foraminifera, calcareous nannoplankton, $\delta^{18} \mathrm{O}$, magnetostratigraphy, sequence stratigraphy) which can be applied in widely different settings. The selected calcareous plankton events appear to be synchronous between the Mediterranean and the low-latitude open ocean on the basis of the existing astronomical age models. In addition, the $D$. kugleri LCO is tightly linked to the short normal subchron C5r.2n (Raffi et al., 1995). Moreover, this event coincides closely with the Mi-5 isotope event and the associated glacio-eustatic sea-level lowstand (TB3.1) and deep-sea hiatus NH4.

The use of D. kugleri needs some taxonomic clarification. Our concept of $D$. kugleri fits exactly with the original description of the species (Martini and Bramlette, 1963) and has the same variability in morphology as documented in the original paper with a large and flat central area without a central knob. However, the identification of $D$. kugleri is problematical when preservation is poor because other discoasters having a similar morphology (e.g., D. musicus with $D$. sanmiguelensis as a junior synonym) can be confused with overgrown D. kugleri. In addition, a higher than average sample resolution is necessary to reliably detect this event.

G. subquadratus is a taxon easily recognizable and its test morphology makes it readily identifiable from other species in this interval. The G. subquadratus LCO is an event easily detectable by the sharp decrease of the species. Only rare and scattered specimens are found at younger levels. The event is very close to the G. obliquus FCO.

\section{Selecting the section to define the boundary}

The historical stratotype section of Rio Mazzapiedi-Castellania is considered unsuitable for defining the Tortonian GSSP because the section has not been astronomically tuned and contains considerable numbers of reworked microfossils. In addition it does not contain the boundary interval selected above. Tuned candidate sections for defining the GSSP are the Monte Gibliscemi and Case Pelacani sections on Sicily (southern Italy: Hilgen et al., 2000b; Caruso et al., 2002), the Monte dei Corvi section in northern Italy (Hilgen et al., 2003) and the San Nicola section on Tremiti islands (Adriatic Sea, Italy: Lirer et al., 2002).

Of all candidate sections Monte dei Corvi is the only section that is demonstrable continuous, shows a near lack of tectonic disturbance, is excellently exposed and easily accessible and can be unambiguously tuned in the critical interval across the boundary. The Monte Gibliscemi section is tectonically severely disturbed while the Case Pelacani and San Nicola sections are less well exposed in the boundary interval. Clearly this strengthens the case for Monte dei Corvi to define the Tortonian GSSP as previously suggested by Montanari et al. (1997) and Odin et al. (1997). The section can be correlated cyclostratigraphically in detail to sections on Sicily (Monte Gibliscemi, Case Pelacani) and the Tremiti Islands (San Nicola). Serious shortcomings are the moderate to poor preservation of the calcareous plankton. The preservation problem certainly hampers to establish a reliable stable isotope record but detailed biostratigraphic correlations to other Mediterranean sections marked by a better preservation are straightforward. The initial lack of a reliable magnetostratigraphy in the critical interval (Montanari et al., 1997; Hilgen et al., 2003) has since been overcome by a detailed paleomagnetic analysis of a new high-resolution sample set (unpubl. data).

\section{The Tortonian GSSP at Monte Dei Corvi}

The Monte dei Corvi Beach section is exposed in the coastal cliffs of Monte dei Corvi located $5 \mathrm{~km} \mathrm{SE}$ of Ancona (Italy) at a latitude of $43^{\circ} 35^{\prime} 12^{\prime \prime}$ North and a longitude of $13^{\circ} 34^{\prime} 10^{\prime \prime}$ East of Greenwich. The section is very easy to reach from Ancona and is freely and easily accessible to scientists interested in studying the section (Figures $4,5)$. The section can best be reached via the trail that starts at $\mathrm{La}$ Sardella some $100 \mathrm{~m}$ east of Monte dei Corvi (Figure 4).

The coastal cliff exposures of Monte dei Corvi contain the Middle to Upper Miocene part of the succession exposed along the Cònero Riviera. They were first measured and studied in detail by Sandroni (1985), and subsequently re-measured and sampled by 


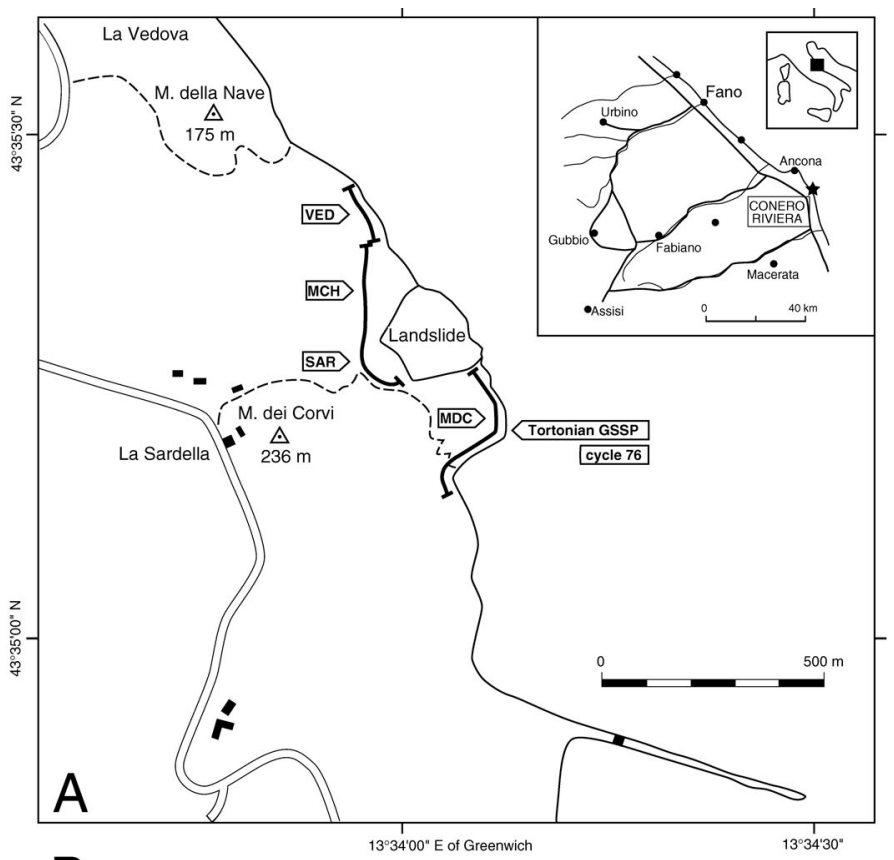

\section{B}
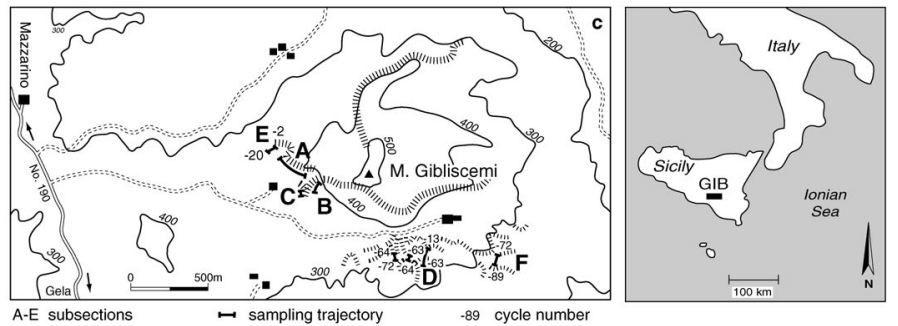

Figure 4 Location map for the boundary stratotype section of Monte dei Corvi $(A)$ and $(B)$ the auxiliary boundary stratotype section of Monte Gibliscemi (after Hilgen et al., 2003). The partial sections that combined make up the Gibliscemi composite are in stratigraphic order F,D,C,B and A (see Hilgen et al., 1995, $2000 b$ for details).

Montanari et al., 1988). The sequence is exposed in three main outcrops (see Montanari et al., 1997 and Figure 4): 1) the Monte dei Corvi Beach section along the beach; 2) the La Sardella - Monte dei Corvi High Cliff composite section high up on the cliff, along the scarp of a large landslide, and; 3) the La Vedova section along the seashore bluffs and cliffs at the locality known as La Vedova. Integrated stratigraphic data are provided by Montanari et al. (1997) who studied the entire composite section and by Hilgen et al. (2003) who focused their attention exclusively on the excellently exposed Monte dei Corvi Beach section (Figure 5). It is the latter section that contains the proposed Tortonian GSSP (Figures 5, 6).

\section{Geological setting}

The Miocene succession of Monte dei Corvi is particularly suitable for integrated stratigraphic studies because it occupied a relative external position with respect to the developing Apenninic orogen at that time (Montanari et al., 1997). For this reason the succession remained pelagic throughout most of the Miocene, being affected by the NE-ward prograding orogenic front of the Apennines and its associated flysch-like sedimentation at a late, post Miocene stage (Montanari et al., 1997).

\section{Stratigraphic succession}

The entire succession exposed along the cliffs from Ancona to Porto Nouvo extends from the Aquitanian into the Pliocene and con-
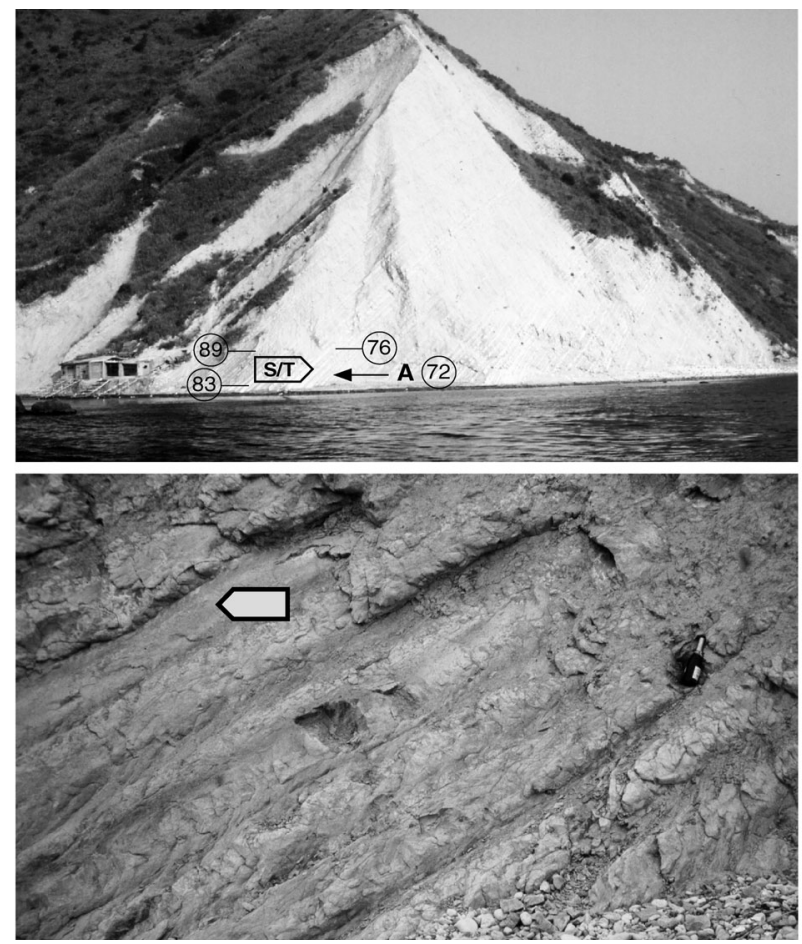

Figure 5 Photograph of the older part of the Monte dei Corvi Beach section of Montanari et al. (1997) and of the Serravallian/Tortonian boundary interval. The S/T boundary and numbered basic sedimentary cycles are indicated (cycle numbers after Hilgen et al., 2003). The arrow marks the Tortonian GSSP and the (empty) bottle the Ancona ash bed.

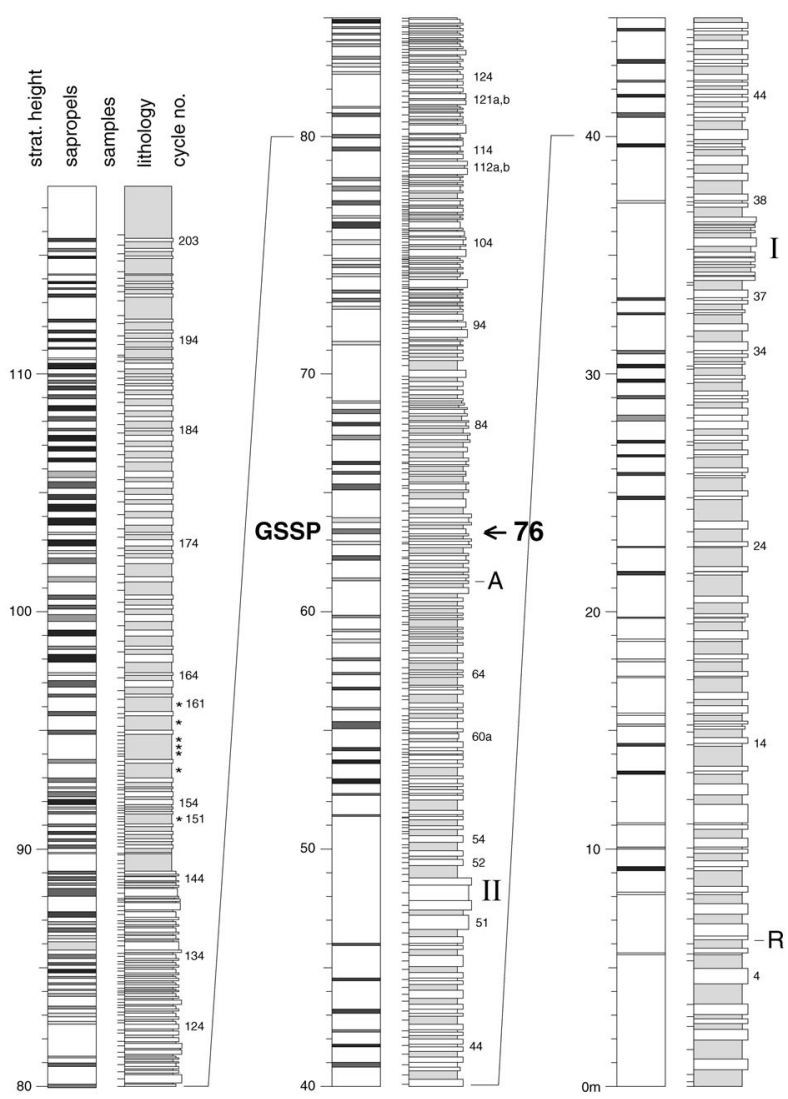

Figure 6 Lithological log of the Monte dei Corvi Beach section (after Hilgen et al., 2003). The two ash beds are indicated by a $R$ (Respighi level) and A (Ancona level). I and II refer to two thick intervals in which it is difficult to ascertain the individual basic sedimentary cycles. 


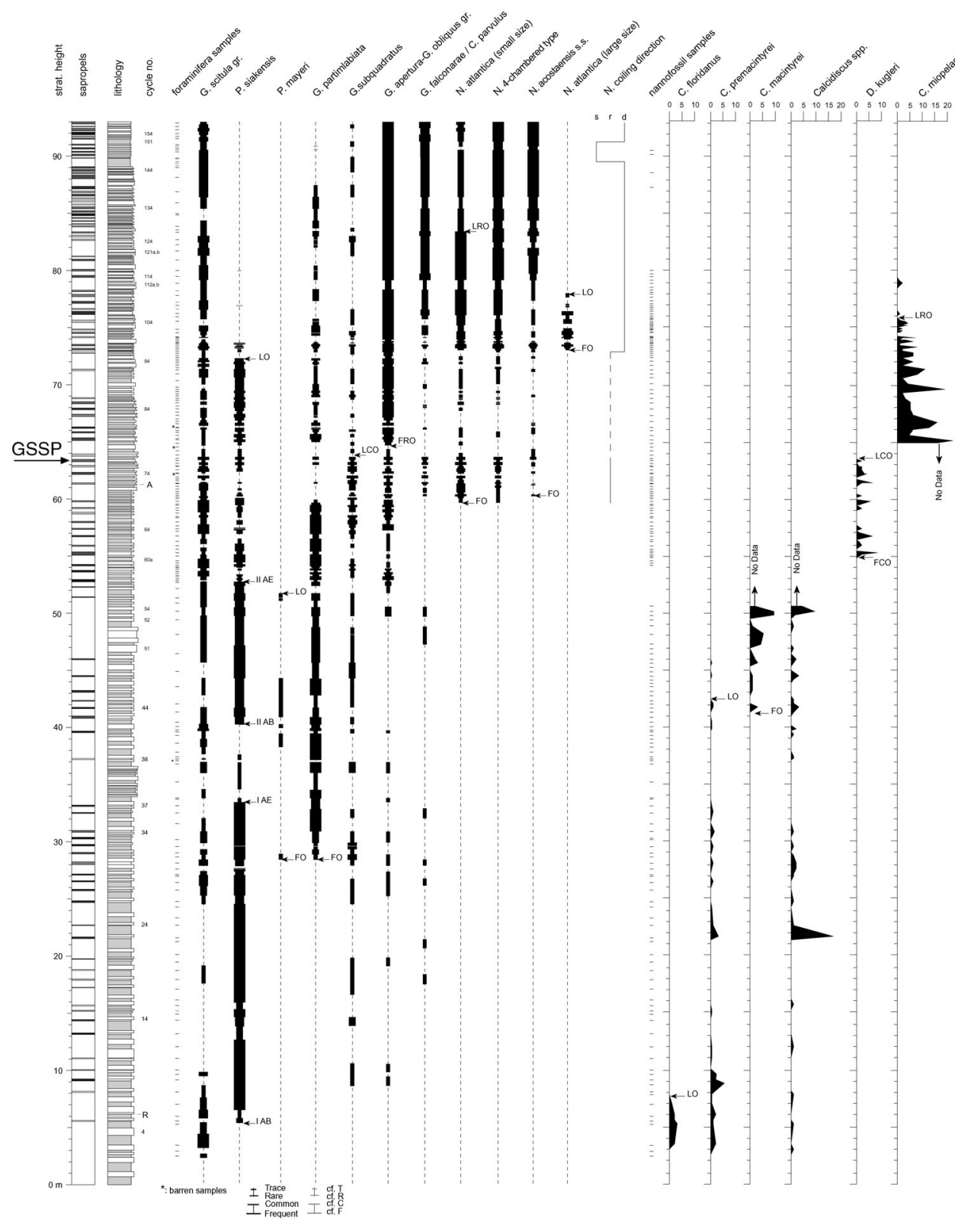

Figure 7 Calcareous plankton biostratigraphy of the Monte dei Corvi Beach section (after Hilgen et al., 2003). No useful data indicates that the marker species has not been counted in this interval because the data would have had no biostratigraphic significance.

\section{Depositional environment}

The depositional environment remained (hemi)pelagic throughout the succession exposed in the Monte dei Corvi : Beach section. Restricted conditions leading to the deposition of the so-called euxinic shales and eventually evaporites associated with the Messinian salinity crisis start higher up in the succession. Bottom water conditions changed cyclically between oxic (marls) and anoxic or dysoxic (sapropel layers).

\section{Calcareous nannofossil biostratigraphy}

Calcareous nannofossils are abundant but their preservation is generally moderate to poor, being better in the sapropel layers. Quantitative biostratigraphic studies of the calcareous nannofossils were carried out by Montanari et al. (1997) and Hilgen et al. (2003; Figure 7). Combining the results of these studies, the following succession of events is recorded (in stratigraphic order): Cyclicargolithus floridanus LO, Calcidiscus macintyrei $\mathrm{FO}, C$. premacintyrei LO, Discoaster kugleri FCO and LCO, last regular occurrence (LRO) of Coccolithus miopelagicus, Helicosphaera walbersdorfensis $\mathrm{LO}$ and $H$. stalis FCO, D. bellus FO, and D. hamatus FO. This order of events is essentially the same as found in other Mediterranean sections such as Monte Gibliscemi (Hilgen et al., 2000b), Case Pelacani (Caruso et al., 2002) and San Nicola (Lirer et al., 2002). The GSSP closely coincides with the Discoaster kugleri LCO and thus with the MNN7b-c zonal boundary in terms of the standard Mediterranean zonation (Raffi et al., 2003). It falls within Zone NN7 of the standard low-latitude zonation of Martini (1971) and in Zone CN6 of the Okada and Bukry (1980) zonation.

\section{Planktonic foraminiferal biostratigraphy}

tains the Bisciaro (Aquitanian to Langhian), Schlier (Langhian to Tortonian), Euxinic Shale and Gessoso Solfifera (Messinian) Formations of the northern Apennines (Montanari et al., 1997). In this paper we concentrate on the Serravallian and Lower Tortonian part of the succession exposed along the eastern slopes and in the coastal cliffs of Monte dei Corvi described in detail by Montanari et al. (1997) and Hilgen et al. (2003). This interval is particularly well exposed in the Monte dei Corvi Beach section of Montanari et al. (1997). This section contains the upper part of the marly Schlier Formation (upper part calcareous member and basal part marly member) and consists of a cyclic alternation of greenish-grey marls, whitish marly limestones and brown coloured organic-rich layers (sapropels). In addition, two biotite-rich volcanic ash layers, named Respighi and Ancona, are present (Figure 6). This part of the succession is underlain by the calcareous marls of the massive member of the middle Schlier exposed in section La Vedova and overlain by marls and euxinic shales of the Euxinic Shale Formation exposed in section La Sardella (Montanari et al., 1997).
Planktonic foraminifera are usually abundant but their preservation is often moderate to poor. The qualitative studies of Coccioni et al. $(1992 ; 1994)$ of the entire composite section allowed to identify all the events employed in the regional zonal scheme of Iaccarino and Salvatorini (1982) and Iaccarino (1985), whereas only few events of the standard low-latitude zonation of Blow (1969) were recognised. The entire composite section ranges from Zone N8 to N17 (Montanari et al., 1997).

The semi-quantitative biostratigraphic analysis presented in Hilgen et al. (2003) focused on the Monte dei Corvi Beach section and allowed the recognition of some additional events in the boundary interval (Figure 7). The FO of the Neogloboquadrina group, including $N$. acostaensis, previously recognised at Monte Gibliscemi and dated at $11.781 \mathrm{Ma}$, was also found at Monte dei Corvi, dated at $11.762 \mathrm{Ma}$. The G. subquadratus LCO dated at $11.539 \mathrm{Ma}$ in the Monte Gibliscemi section was found at a slightly older level at Monte dei Corvi (at $11.593 \mathrm{Ma}$ ). It is preceeded by the Neogloboquadrina group FO and the Paragloborotalia mayeri (sensu Foresi et al., 1998) LO and succeeded by the G. apertura-G. obliquus group 
FRO, the $P$. siakensis ( $=$ P. mayeri sensu Hilgen et al., 2000b) LO and the large-sized $N$. atlantica FO. The GSSP falls within the $P$. siakensis Zone of Iaccarino (1985), coincides with the boundary between $N$. continuosa and G. menardii Zones of Foresi et al. (1998), and the boundary between N. atlantica praeatlantica and $P$. siakensis Zones of Sprovieri et al. (2002). Application of the standard low-latitude zonation of Blow (1969) is rather useless in view of the strong diachroneity of some of the zonal marker events. For example the zonal markers for N14/N15 and N15/N16 fall apart at Ceara Rise (equatorial Atlantic) but overlap in the Mediterranean. At Ceara Rise the guiding criteria for the base Tortonian fall slightly above the G. nepenthes FO (Turco et al., 2002) which event marks the N13/N14 zonal boundary of Blow (1969). In the Carribean Sea, the boundary also falls in the lower part of N14 (Chaisson and D'Hondt, 2000).

\section{Magnetostratigraphy}

A detailed paleomagnetic study of the Monte dei Corvi Beach section has been carried out by Montanari et al. (1997) and Hilgen et al. (2003) with the main purpose to determine the magnetic reversal stratigraphy of the section. Applying standard demagnetisation techniques, Montanari et al. (1997) concluded that the magnetic intensity

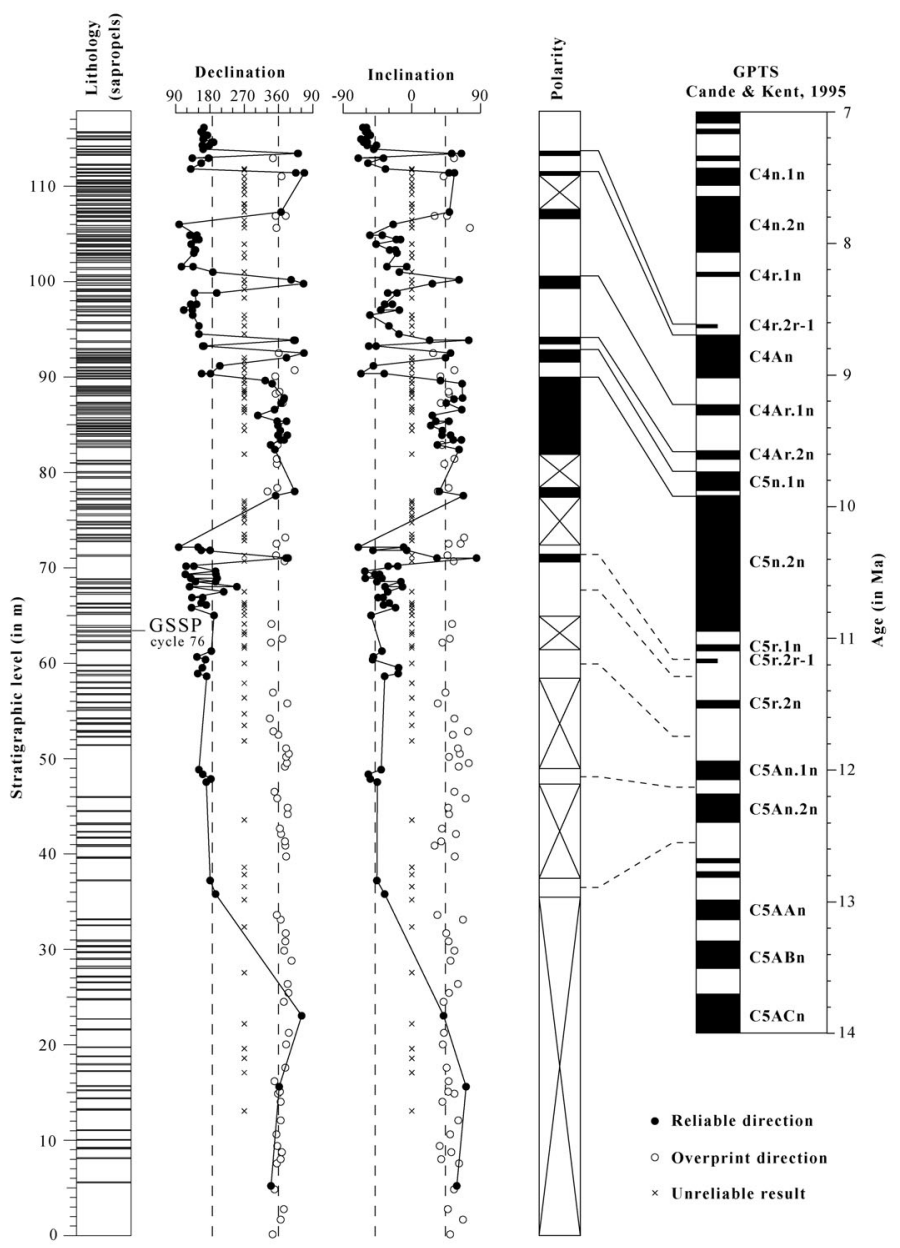

Figure 8 Magnetostratigraphy of the Monte dei Corvi Beach section and calibration to the GPTS of Cande and Kent (1995; based on Hilgen et al., 2003). Note that new unpublished magnetostratigraphic data have not been included in the present figure. Due to the higher resolution, the new data much better constrain the position of the reversals boundaries in the upper $(\sim 35 \mathrm{~m})$ part of the section. Moreover, they provide reliable data for the middle part of the section (i.e. from $\sim 50$ to $\sim 80 \mathrm{~m}$ ), pinpointing all polarity reversal down to the base of C5An.1n and confirming the link between the Tortonian GSSP and C5r.2n. was too weak to yield useful information on the magnetic polarity and that the natural remanent magnetisation (NRM) was already largely removed at temperatures of $200^{\circ} \mathrm{C}$. Most samples revealed southwesterly declinations and negative inclinations, but these directions were considered as an overprint.

A pilot study of a limited number of oriented hand-samples similarly revealed weak to very weak NRM intensities, but also some levels with opposite reversed and normal polarity directions. Subsequent analysis of a more detailed sample set made it possible to isolate a characteristic low-temperature component marked by dual polarities (Hilgen et al., 2003). Plotting the ChRM directions resulted in a magnetostratigraphy for the upper part of the section that could be calibrated to the GPTS of Cande and Kent (1995) and ranges from $\mathrm{C} 5 \mathrm{n} .2 \mathrm{n}$ up to $\mathrm{C} 4 \mathrm{r}$.2r (Figure 8).

At first, the lower part of the section, including the SerravallianTortonian boundary interval, did not produce a reliable magnetostratigraphy in first instance despite the fact that some short reversed intervals were recorded (Figure 8). But the initial lack of a reliable magnetostratigraphy in the critical interval has been overcome in the meantime by a more detailed paleomagnetic analysis of a new sample set with a much higher resolution (unpubl. data). The resulting magnetostratigraphy for the critical middle part of the section can be calibrated straightforwardly to the GPTS of Cande and Kent (1995) and Lourens et al. (2004) and ranges from C5n.2n down to at least C5An.1n. The boundary is, as anticipated, closely associated with the base of - the short normal subchron C5r.2n. Finally, the tuned ages for the newly determined magnetic reversal boundaries at Monte dei Corvi are in very good to excellent agreement with the tuned ages for the same reversals in the continental Orera section in Spain (Abdul Aziz et al., 2003).
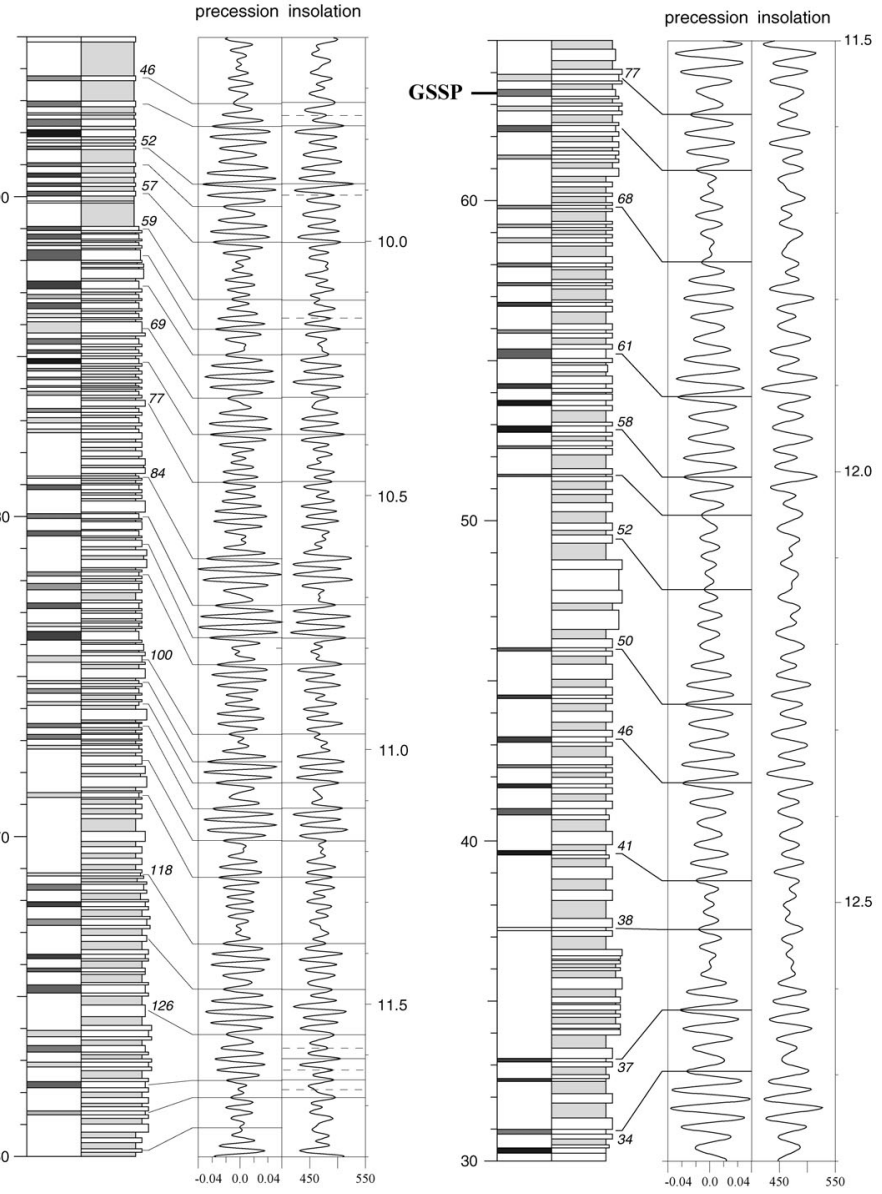

Figure 9 Astronomical tuning of the basic sedimentary cycles in the Serravallian/Tortonian boundary interval in the Monte dei Corvi Beach section to precession and insolation (after Hilgen et al., 2003). 


\section{Cyclostratigraphy and astrochronology}

The Monte dei Corvi Beach section is composed of a cyclic alternation of marls, marly limestones and organic-rich beds (Montanari et al., 1997). The basic small-scale cycle is a couplet (between 0.3 and $1.0 \mathrm{~m}$ thick) which consists of an indurated whitish marly limestone and a softer grey to greenish-grey marl. Brownish to blackish coloured organic-rich beds termed sapropels are frequently but not always intercalated in the limestones. Basic cycles have been labelled from the base of the section upward by assigning consecutive numbers to the limestone beds or the corresponding sapropels (Figure 6).

Larger-scale cycles can be distinguished in addition and comprise both small-scale and large-scale sapropel clusters. Small-scale clusters contain 2 to 4 sapropels (and 5-6 basic cycles); large-scale clusters contain several small-scale clusters (and up to 20 basic cycles). Finally a cycle of intermediate-scale is recognised by repetitive sapropel patterns in every other basic cycle. Previous studies of marine sections of Late Miocene to Pleistocene age in the Mediterranean (Hilgen, 1991; Lourens et al., 1996) showed that similar sapropel patterns reflect the astronomical cycles of precession (basic cycle), obliquity (intermediate cycle) and eccentricity (larger-scale cycles). Using the same phase relations as established for the younger sapropels, the sedimentary cycles in the Monte dei Corvi Beach section were tuned to the precession and insolation time series of the La93 solution (Laskar, 1990; Laskar et al., 1993). This tuning provides astronomical ages for all the sedimentary cycles, calcareous plankton bioevents, magnetic reversals and ash beds recorded in the section (Figure 9). It shows that the entire beach section ranges from 13.4 to 8.5 Ma and that the Tortonian GSSP has an astronomical age of 11.608 Ma (Hilgen et al., 2003; see Figure 9). Application of the new full numerical solution La2004 (Laskar et al., 2004) will not seriously affect the tuning and result in minor changes in the astronomical ages only (in the order of several kyr).

Note that our preferred tuning deviates from the eccentricity tuning proposed by Cleaveland et al. (2002). The latter tuning is based on a high-resolution carbonate record and is consistent with the previously published ${ }^{40} \mathrm{Ar} /{ }^{39} \mathrm{Ar}$ biotite ages from the ash beds, but not with unpublished sanidine ages for the Ancona bed (see below). However, their tuning can easily be modified as to fit the tuning of Hilgen et al. (2003) and followed in the present paper.

\section{Ar/Ar chronology}

The composite sequence at Monte dei Corvi contains numerous ash layers, most of which are concentrated in a relatively short interval across the Tortonian/Messinian boundary. Two biotite-bearing ash layers, named Respighi and Ancona, are found in the Monte dei Corvi Beach section, the latter one being intercalated only $2 \mathrm{~m}$ below the proposed GSSP. Fresh unaltered biotites from both these ash layers have been dated using the incremental-heating ${ }^{40} \mathrm{Ar} /{ }^{39} \mathrm{Ar}$ technique (Montanari et al., 1997). For the Respighi layer, the preferred mean isochron age (of 3 out of 4 experiments) arrived at $12.86 \pm 0.16$ $\mathrm{Ma}$, while a weighted average of two plateau ages (of a single experiment) of $11.43 \pm 0.20 \mathrm{Ma}$ was obtained for the Ancona bed. These ages were calculated relative to an age of 27.84 Ma for the Fish Canyon Tuff sanidine monitor dating standard and they arrive at 12.94 and $11.51 \mathrm{Ma}$ if the recently published age of $28.02 \mathrm{Ma}$ for this standard is applied (Renne et al., 1998). These ages are slightly but significantly younger than the astronomical ages of 13.296 and 11.688 Ma for the same ash layers (Hilgen et al., 2003). However a recent intercalibration study arrives at an astronomically calibrated age of $28.24 \pm 0.01 \mathrm{Ma}$ for the FCT sanidine while single fusion experiments on sanidine from the Ancona ash yield an age of 11.68 $\pm 0.02 \mathrm{Ma}$ that is virtually identical to the preferred astronomical age (Kuiper, 2003; Kuiper et al., 2005).

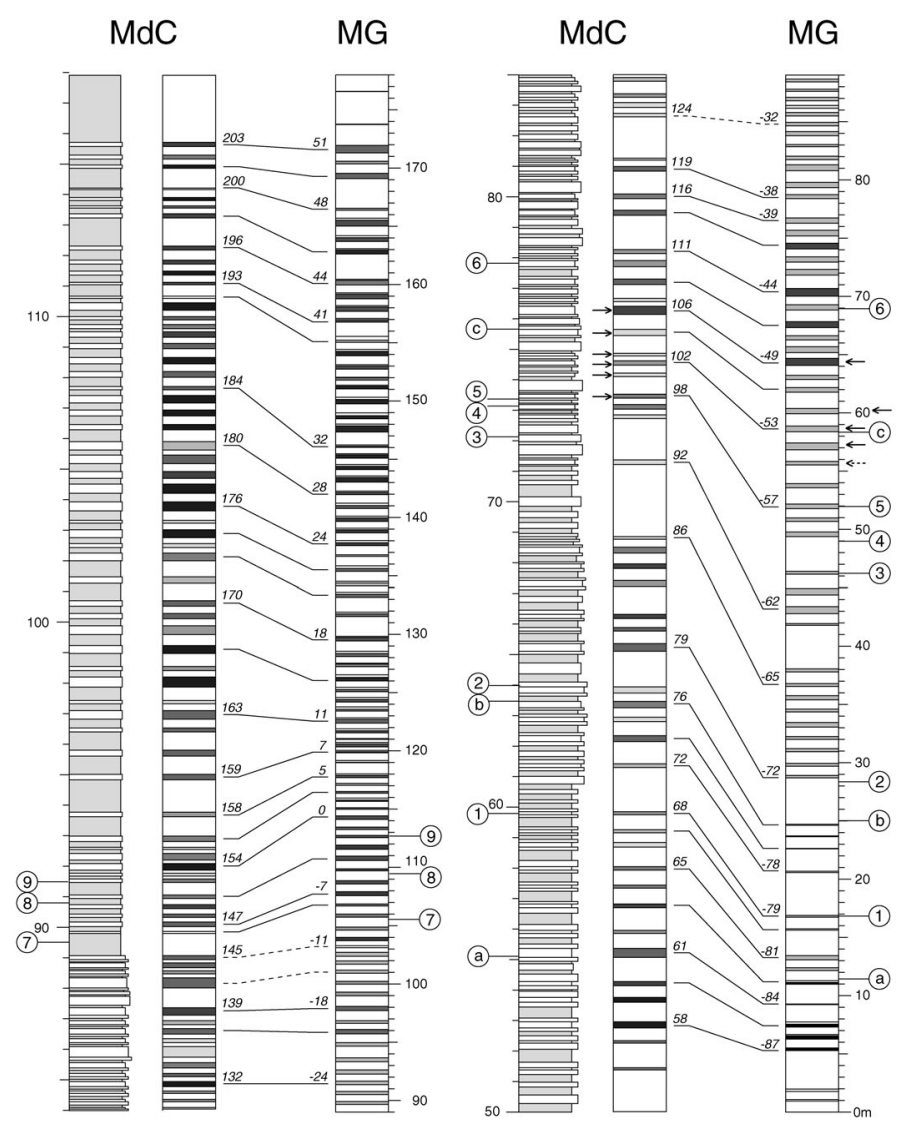

Figure 10 Integrated cyclostratigraphic and biostratigraphic correlations between the Monte dei Corvi Beach section (MdC) and the Monte Gibliscemi section (MG) (after Hilgen et al., 2003). The part of the Gibliscemi composite shown here is based on partial sections $F, D, C$ and $B$ (see Hilgen et al., 1995, $2000 b$ for details). Numbered calcareous plankton events refer to: (1) Neogloboquadrina group FO, (2) G. subquadratus LCO, (3) P. siakensis $L O$, (4) Neogloboquadrina group second influx, (5) N. atlantica large-sized $\mathrm{FO}$, (6) N. atlantica large-sized $\mathrm{LO}$, (7) Neogloboquadrina dextral to sinistral coiling shift, (8) G. partimlabiata $L O$, (9) Neogloboquadrina sinistral to dextral coiling shift, a) D. kugleri $F C O, b) \mathrm{D}$. kugleri $L C O$, and c) $\mathrm{C}$. miopelagicus LRO. (Dashed) arrows mark major (minor) influxes of large-size $\mathrm{N}$. atlantica.

\section{Sr-isotope stratigraphy}

The Sr-isotope composition of whole rock, isolated foraminiferal tests and fish teeth has been analysed in samples from the Monte dei Corvi Beach and La Sardella sections (Montanari et al., 1997). The isotope composition of the whole rock samples from the Monte dei Corvi Beach section is generally consistent with ${ }^{87} \mathrm{Sr} /{ }^{86} \mathrm{Sr}$ values in pelagic carbonates from the open ocean. On the other hand, samples (of widely different materials) from the Messinian La Sardella section exhibit Sr-isotope ratios that are significantly lower than those obtained from the open ocean. This deviation can best be explained by an increasing isolation of the Mediterranean Basin, or partially so, from the world's oceans (Montanari et al., 1997).

\section{Stable isotopes}

Unfortunately, a reliable stable isotope record can not be obtained due to the moderate to poor preservation of the foraminiferal tests. The Monte dei Corvi Beach section can be correlated cyclostratigraphically in detail with the Monte Gibliscemi section (Figure 10) from which a planktic and benthic isotope record is available (Turco et al., 2001; Figure 11). This correlation shows 


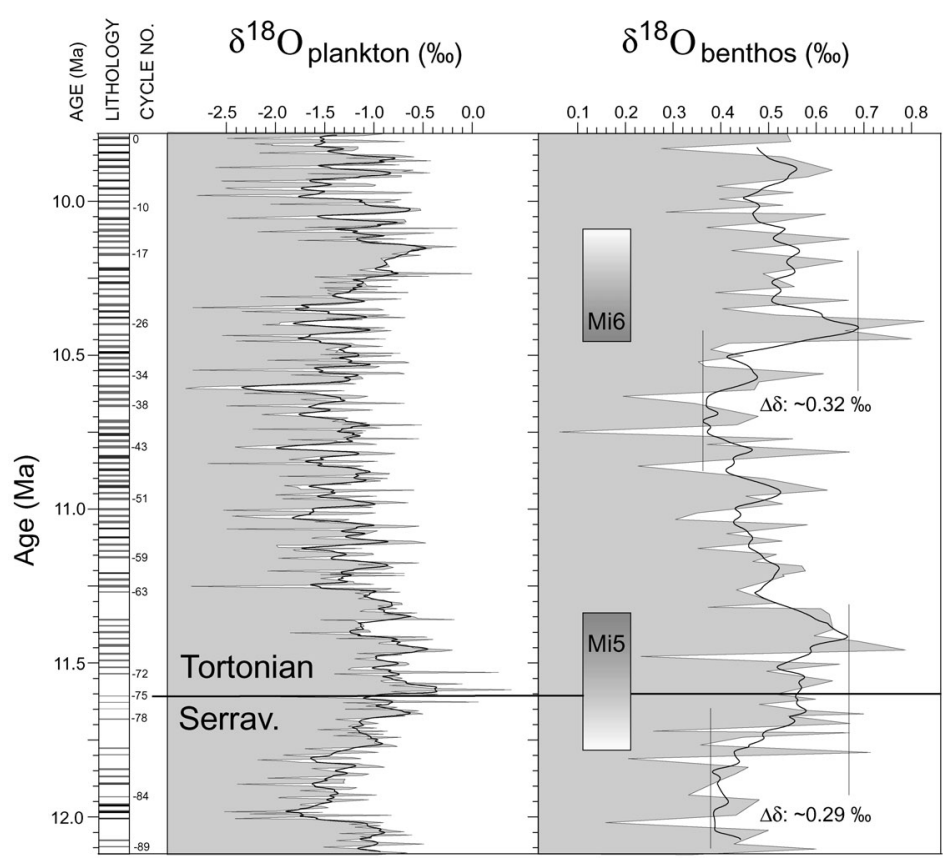

Figure 11 Benthic and planktonic isotope records of the Monte Gibliscemi section showing the position of event Mi-5 (from Turco et al., 2001). The part of the Gibliscemi composite shown is based on partial sections $F$ and $D$ (see Hilgen et al., 2000b for details).

that the Tortonian GSSP slightly predates a short interval marked by heavier $\delta^{18} \mathrm{O}$ values that corresponds to the Mi-5 isotope event of Miller et al. (1991). This event supposedly reflects a temporary increase in Antarctic ice volume linked to minimum amplitude variations in the 1.2 myr obliquity cycle (Turco et al., 2001).

\section{Completeness of the section}

The unambiguous orbital tuning of the sedimentary cycles in the boundary interval cannot be explained other than that the succession is continuous. The tuning provides a highly accurate age of 11.608 Ma for the boundary. The section can further be correlated bed-to-bed to other marine sections in the Mediterranean (Figures $10,11)$. The cyclostratigraphic correlations are confirmed in detail by the high-resolution calcareous plankton biostratigraphy, thus providing another argument for the continuity of the succession. Sediment accumulation rates can be accurately determined and are in the order of 3-4 cm/kyr in the boundary interval.

\section{Definition, position, and identification of the boundary}

The Serravallian/Tortonian boundary and hence the base of the Tortonian Stage is defined at the midpoint of the sapropel layer of small-scale sedimentary cycle no. 76 in the Monte dei Corvi Beach (Figure 6; Hilgen et al., 2003). The level coincides almost exactly with the base of the short normal subchron C5r.2n and the last common occurrences (LCOs) of the calcareous nannofossil Discoaster kugleri and the planktonic foraminifer Globigerinoides subquadratus (Figure 7), and is located stratigraphically $2 \mathrm{~m}$ above the Ancona ash layer (Figure 8). The level has been assigned an astronomical age of 11.608 Ma (Figure 9). We selected the sapropel midpoint instead of sapropel base (as has been common practise in defining GSSPs of Neogene stages up to now) because it is the midpoint that is assigned the age of the correlative peak in the astronomical target curve. The midpoint of the sapropel layer of cycle 76 will be marked in the field. Identification of the GSSP and re-sampling of the section are greatly facilitated by the readily identifiable sedimentary cycle pattern in the field.

\section{Auxiliary boundary stratotype}

We designate section Gibliscemi, exposed along the southern slopes of Monte Gibliscemi located on Sicily (Italy) as an auxiliary boundary stratotype for the Serravallian-Tortonian boundary. This designation is meant to overcome the problem of the poor to moderate preservation of the calcareous microfossils observed at Monte dei Corvi, which also prevents us from establishing a reliable stable isotope record. The Gibliscemi section has been correlated cyclostratigraphically in detail ("bed-to-bed") to the Monte dei Corvi section, the cyclostratigraphic correlations being confirmed by the calcareous plankton biostratigraphy (Figure 10). At Monte Gibliscemi the S/T boundary is placed at the mid-point of the grey marl bed of small-scale cycle -75 in subsection D located at $24.67 \mathrm{~m}$ in the Gibliscemi composite of Hilgen et al. (2000b). The marl bed correlates with the sapropel of cycle 76 at Monte dei Corvi (Figure 10) and coincides closely with the D. kugleri LCO. In addition, four volcanic ash layers are found in the basal part of section Gibliscemi which contain sanidine in a datable fraction. The Ar/Ar ages for the most suitable of the ash layers are in agreement with the astronomical ages for these layers (Kuiper, 2003; Kuiper et al., 2005).

The integrated calcareous plankton biostratigraphy and astronomical tuning of the section were presented in Hilgen et al. (2000b) while the quantitative planktonic foraminifer record, and the planktonic and benthic stable isotope records were published in Turco et al. (2001). The planktonic and benthic isotope records are punctuated by two episodes of $\delta^{18} \mathrm{O}$ increase (Figure 11) which have been assigned astronomical ages of around 11.4 and 10.4 Ma and correspond to the Mi5 and Mi6 events of Miller et al. (1991). The expression of the Mi5 event thus slightly postdates the $\mathrm{S} / \mathrm{T}$ boundary as proposed here.

\section{Regional exportation of the boundary}

Integrated stratigraphic correlations of the Tortonian GSSP to other Mediterranean sections are straightforward and unambiguous. High-resolution cyclostratigraphic correlations are confirmed in detail by the position of calcareous plankton events. This applies both to major bio-events such as the Discoaster kugleri FCO and LCO, the G. subquadratus LCO, and the Neogloboquadrina group FO and to secondary events such as the G. apertura-G. obliquus group FRO. The magnetobiostratigraphic record of continental sections in Spain shows that the GSSP predates the Hipparion FO with a minimum age of 11.1 Ma (Garcés et al., 1997) and, thus, the Aragonian/Vallesian stage boundary by some amount of time.

\section{Global exportation of the boundary}

The concurrence of the Tortonian GSSP with subchron C5r.2n has now been confirmed by new magnetostratigraphic data from the boundary stratotype section itself. The association allows identification of the boundary in continental settings lacking a direct biostratigraphic control. In the marine realm, the D. kugleri and G. subquadratus LCOs appear to be synchronous between the Mediterranean type area and the low-latitude open ocean (Backman and Raffi, 1997; Hilgen et al, 2000b; Turco et al., 2002).

Stable isotopes yet provide another useful correlation tool. The boundary slightly predates the Mi-5 isotope event of Miller et al. (1991) dated astronomically at 11.4 Ma in the Monte Gibliscemi section (Turco et al., 2001; Figure11) and the associated glacio-eustatic sea-level low-stand of supercycle T3.1 (Haq et al., 1987) and concurrent deep-sea hiatus NH4 of Keller and Barron (1983). The boundary further coincides almost exactly with the BarstovianClarendonian Mammal Age boundary in North America (Woodburne and Swisher, 1995; Alroy, 2002). 


\section{References}

Abdul Aziz, H., Hilgen, F.J., Krijgsman, W., and Calvo, J.P., 2003, An astronomical polarity time scale for the late middle Miocene based on cyclic continental sequences: J. Geophys. Res., v. 108, 2159.

Alroy, J., 2002, A quantitative North American Time Scale (http: //www.nceas.ucsb.edu/ alroy).

Backman, J., and Raffi, I., 1997, Calibration of Miocene nannofossil events to orbitally-tuned cyclostratigraphies from Ceara Rise: Proc. ODP, Sci. Res., v. 154, pp. 83-99.

Berggren, W.A., Kent, D.V., Swisher, C.C., and Aubry, M.-P., 1995, A revised Cenozoic geochronology and chronostratigraphy, in Geochronology, Time Scales and Global Stratigraphic Correlation, SEPM Spec. Publ., v. 54, pp. 129-212.

Blow, W.H., 1969, Late middle Eocene to Recent planktonic foraminiferal biostratigraphy, in Bronniman, P., and Renz, R.R., eds., Proc. First. Int. Conf. Planktonic Microfossils, Geneva, 1967, v. 1, pp. 199-422, Leiden.

Cande, S.C., and Kent, D.V., 1995, Revised calibration of the Geomagnetic Polarity Time Scale for the Late Cretaceous and Cenozoic: J. Geophys. Res., v. 100, pp. 6093-6095.

Caruso, A., Sprovieri, M., Bonanno, A., and Sprovieri, R., 2002, Astronomical calibration of the Serravallian-Tortonian Case Pelacani section (Sicily, Italy), in Iaccarino, S., ed., Integrated stratigraphy and paleoceanography of the Mediterranean Middle Miocene: Riv. It. Paleont. Strat., v. 108, pp. 297-306, Milano.

Castradori, D., Rio, D., Hilgen, F.J., and Lourens, L.J., 1998, The Global Standard Stratotype section and Point (GSSP) of the Piacenzian Stage (Middle Pliocene): Episodes, v. 21, pp. 88-93.

Chaisson, W.P., and d'Hondt, S.L., 2000, Neogene planktonic foraminifer biostratigraphy at Site 999, western Carribean Sea, in Leckie, R.M., Sigurdsson, H., Acton, G.D., and Draper, G., eds., Proc. ODP, Sci. Results, v. 165: College Station TX (Ocean Drilling Program), pp. 19-56.

Cita, M.B., Premoli Silva, I., and Rossi, R., 1965, Foraminiferi planctonici del Tortoniano-tipo: Riv. Ital. Paleontol. Stratigr., v. 71, pp. 217-308.

Cita, M.B., and Blow, W.H., 1969, The biostratigraphy of the Langhian, Serravallian and Tortonian Stages in the type-sections in Italy: Riv. It. Paleont. Strat., v. 75, pp. 549-603.

Clari, P., and Ghibaudo, G., 1979, Multiple slump scars in the Tortonian type area (Piedmont Basin, Northwestern Italy): Sedimentology, v. 26, pp. 719-730.

Cleaveland, L.C., Jensen, J., Goese, S., Bice, D.M., and Montanari, A., 2002, Cyclostratigraphic analysis of pelagic carbonates at Monte dei Corvi (Ancona, Italy) and astronomical correlation of the Serravallian-Tortonian boundary: Geology, v. 30, pp. 931-934.

Coccioni, R., Di Leo, C., and Galeotti, S., 1992, Planktonic foraminiferal biostratigraphy of the upper Serravallian-lower Tortonian Monte dei Corvi section (NE Apennines, Italy), in Montanari, A., et al., eds., Conferenza interdiscplinare di geologia sull'Epoca miocenica con enfasi sulla sequenza umbro-marchigiana, Ancona 1992, Miocene Columbus Project. Abstr. and Field trips, pp. 53-56.

Coccioni, R., Galeotti, S., and Di Leo, R., 1994, The first occurrence of Neogloboquadrina atlantica (Berggren) in the Mediterranean: Giorn. Geol., v. 56, pp. 127-138.

d'Onofrio, S., Giannelli, L., Iaccarino, S., Morlotti, E., Romeo, M., Salvatorini, G., Sampò, M., and Sprovieri, R., 1975, Planktonic foraminifera of the Upper Miocene from some Italian sections and the problem of the lower boundary of the Messinian: Boll. Soc. Paleont. It., v. 14, pp. 177196.

Foresi, L.M., Iaccarino, S., Mazzei, R., and Salvatorini, G., 1998, New data on Middle to Late Miocene calcareous plankton biostratigraphy in the Mediterranean area: Riv. It. Paleont. Strat., v. 104, pp. 95-114.

Garcés, M., Cabrera, L., Agusti, J., and Parés, J.M., 1997, Old world first appearance datum of "Hipparion" horses: Late Miocene large mammal dispersal and global events: Geology, v. 25, pp. 19-22.

Gianotti, A., 1953, Microfaune della serie tortoniana del Rio MazzapiediCatellania (Tortona - Alessandria): Riv. It. Paleont., Mem. VI, pp. 167308.

Ghibaudo, G., Clari, P., and Perello, M., 1985, Lithostratigrafia, sedimentologia ed evoluzione tettonico-sedimentaria dei depositi miocenici del margine sud-orientale del Bacino Terziario Ligure-Piemontese (valli Borbera, Scrivia e Lemme): Boll. Soc. Geol. Ital., v. 104, pp. 349-397.

Gino, G.F., 1953, Osservazioni geologiche sui dintorni di S. Agata Fossili: Riv. It. Paleont. Strat., Mem. VI, pp. 1-23.

Harland, W.B., Amstrong, R., Cox, A.V., Craig, L., Smith, A., and Smith, D., 1990, A Geological Time Scale 1989, Cambridge Univ. Press, Cambridge, $263 \mathrm{pp}$
Haq, B.U., Hardenbol., J., and Vail, P.R., 1987, Chronology of fluctuating sea levels since the Triassic: Science, v. 235, pp. 1156-1167.

Hilgen, F.J., 1991, Astronomical calibration of Gauss to Matuyama sapropels in the Mediterranean and implication for the Geomagnetic Polarity Time Scale: Earth Planet. Sci. Lett., v. 104, pp. 226-244.

Hilgen, F.J., Krijgsman, W., Langereis, C.G., Lourens, L., Santarelli, A., and Zachariasse, W.J., 1995, Extending the astronomical (polarity) time scale into the Miocene: Earth Planet. Sci. Lett., v. 136, pp. 495-510.

Hilgen, F.J., Iaccarino, S., Krijgsman, W., Villa, G., Langereis, C.G., and Zachariasse, W.J., 2000a, The Global boundary Stratotype Section and Point (GSSP) of the Messinian Stage (Uppermost Miocene): Episodes, v. 23, pp. 172-178.

Hilgen, F.J., Krijgsman, W., Raffi, I., Turco, E., and Zachariasse, W.J., $2000 \mathrm{~b}$, Integrated stratigraphy and astronomical calibration of the Serravallian/Tortonian boundary section at Monte Gibliscemi, Sicily: Mar. Micropal., v. 38, pp. 181-211.

Hilgen, F.J., Iaccarino, S., Krijgsman, W., Montanari, A., Raffi, I., Turco, E., and Zachariasse, W.J., 2002, The Global Stratotype Section and Point (GSSP) of the Tortonian Stage (Upper Miocene): A proposal (http://www.geo.uu.nl/sns/).

Hilgen, F.J., Abdul Aziz, H., Krijgsman, W., Raffi, I., and Turco, E., 2003, Integrated stratigraphy and astrochronology of the Serravallian and lower Tortonian at Monte dei Corvi (Middle-Upper Miocene, Northern Italy): Palaeogeogr., Palaeoclim., Palaeoecol., v. 199, pp. 229-264.

Iaccarino, S., and Salvatorini, G., 1982, A framework of planktonic foraminiferal biostratigraphy for early Miocene to late Pliocene in the Mediterranean area: Paleontol. Stratigr. ed Evol., v. 2, pp. 115-125.

Iaccarino, S., 1985, Mediterranean Miocene and Pliocene planktic foraminifera, in Bolli, H.M., Saunders, J.B., and Perch-Nielsen, K., eds., Plankton Stratigraphy, Cambridge Univ. Press, pp. 283-314.

Keller, G., and Barron, J.A., 1983, Paleoceanographic implications of Miocene deep-sea hiatuses: Geol. Soc. Am. Bull., v. 94, pp. 590-613.

Kuiper, K., 2003, Direct intercalibration of radioisotopic and astronomical time in the Mediterranean Neogene: Geologica Ultraiectina, v. 235, 223 pp (see also http://www.geo.vu.nl/users/kuik).

Kuiper, K., Hilgen, F.J. and Wijbrans, J.R., 2005, Radioisotopic dating of the Tortonian GSSP: implications for intercalibration of ${ }^{40} \mathrm{Ar} /{ }^{39} \mathrm{Ar}$ and astronomical dating methods: Terra Nova (in press).

Laskar, J., 1990, The chaotic motion of the solar system: A numerical estimate of the size of the chaotic zones: Icarus, v. 88, pp. 266-291.

Laskar, J., Joutel, F., and Boudin, F., 1993, Orbital, precessional, and insolation quantities for the Earth from $-20 \mathrm{Myr}$ to $+10 \mathrm{Myr}$ : Astron. Astrophys., v. 270 , pp. 522-533.

Laskar, J., Robutel, P., Joutel, F., Gastineau, M., Correia, A.C.M., and Levrard, B., 2004, A long term numerical solution for the insolation quantities of the Earth: Astron. \& Astrophys., v. 428, 261-285.

Lirer, F., Caruso, A., Foresi, L.M., Sprovieri, M., Bonomo, S., Di Stefano, A., Di Stefano, E., Iaccarino, S.M., Salvatorini, G., Sprovieri, R., and Mazzola, S., 2002, Astrochronological calibration of the upper Serravallian-lower Tortonian sedimentary sequence at Tremiti Islands (Adriatic Sea, Southern Italy), in Iaccarino, S., ed., Integrated stratigraphy and paleoceanography of the Mediterranean Middle Miocene: Riv. It. Paleont. Strat., v. 108, pp. 241-256, Milano.

Lourens, L., Hilgen, F.J., Zachariasse, W.J., van Hoof, A.A.M., Antonarakou, A., and Vergnaud-Grazzini, C., 1996, Evaluation of the Plio-Pleistocene astronomical time scale: Paleoceanography, v. 11, pp. 391-413.

Lourens, L.J., Hilgen, F.J., Laskar, J., Shackleton, N.J., and Wilson, D., 2004 The Neogene Period. in Gradstein, F., Ogg, J., et al., (eds), A Geologic Time Scale 2004, Cambridge Univ. Press, UK.

Martini, E., 1971, Standard Tertiary and Quaternary calcareous nannoplankton zonation: Proc. II Planktonic Conf., Roma 1970, v. 2, pp. 739-785.

Martini, E., and Bramlette, M.N., 1963, Calcareous nannoplankton from the experimental Mohole drilling: J. Paleontol., v. 37, pp. 845-856.

Mayer-Eymar, K., 1858, Versuch einer neuen Klassification der Tertiär gebilde Europa's, Verhandl. der Allgemeinen Schweiz. Ges. f. gesammt. Naturwissensch., Trogen, pp. 165-199.

Mayer-Eymar, K., 1868, Tableau synchronistique des terrains Tertiaires supérieurs, IV ed., Zürich.

Mazzei, R., 1977, Biostratigraphy of the Rio Mazzapiedi-Castellania section (type section of the Tortonian) based on calcareous nannoplankton: Att. Soc. Tosc. Sci. Nat. Mem., v. 84, pp. 15-24.

Miculan, P., 1997, Planktonic foraminiferal biostratigraphy of the Tortonian historical stratotype, Rio Mazzapiedi-Castellania section, northwestern Italy, in Montanari, A., Odin, G.S., and Coccioni R., eds., Miocene stratigraphy: An integrated approach, Devel. Palaeontol. Stratigr., v. 15, pp. 97-106. 
Miller, K.G., Wright, J.D., and Fairbanks, R.G., 1991, Unlocking the Ice House: Oligocene-Miocene oxygen isotopes, eustacy and marginal erosion: J. Geophys. Res., v. 96, pp. 6829-6848.

Montanari, A., Langenheim, V.E., and Coccioni, R., 1988, Stratigraphy and geochronological potential of the pelagic and hemipelagic sequence of the northeastern Apennines: A research note: Bull. Liais. Inf., Project 196, 7, pp. 17-23.

Montanari, A., Beaudoin, B., Chan, L.S., Coccioni, R., Deino, A., de Paolo, D.J., Emmanuel, L., Fornaciari, E., Kruge, M., Lundblad, S., Mozzato, C., Portier, E., Renard, M., Rio, D., Sandroni, P., and Stankiewicz, A., 1997, Integrated stratigraphy of the Middle and Upper Miocene pelagic sequence of the Cònero Riviera (Marche region, Italy), in Montanari, A., Odin, G.S., and Coccioni, R., eds., Miocene stratigraphy: An integrated approach: Devel. Palaeontol. Stratigr., v. 15, pp. 409-450.

Müller, C., 1975, Calcareous nannoplankton from type Serravallian, Proc. RCMNS, Bratislava, pp. 49-52.

Odin, G.S, Montanari, A., and Coccioni, R., 1997, Chronostratigraphy of Miocene Stages: A proposal for the definition of precise boundaries, in Montanari, A., Odin, G.S., and Coccioni, R., eds., Miocene stratigraphy: An integrated approach: Devel. Palaeontol. Stratigr., v. 15, pp. 597-629.

Okada, H., and Bukry, D., 1980, Supplementary modification and introduction of code numbers to the low-latitude coccolith biostratigraphic zonation (Bukry, 1973; 1975): Mar. Micropal., v. 51, pp. 321-325.

Raffi, I., Mozzato, C., Fornaciari, E., Hilgen, F.J., and Rio, D., 2003, Late Miocene calcareous nannofossil biostratigraphy and astrobiochronology for the Mediterranean region. Micropaleontology: v. 49, pp. 1-26.

Raffi, I., Rio, D., d'Atri, A., Fornaciari, E., Rocchetti, S., 1995, Quantitative distribution patterns and biomagnetostratigraphy of Middle to Late Miocene calcareous nannofossils from equatorial Indian and Pacific Oceans (Legs 115, 130, and 118), Proc. ODP, Sci. Results: v. 138, 479-502.

Remane, J., Bassett, M.G., Cowie, J.W., Gohrbrandt, K.H., Richard Lane, H., Michelsen, O., and Naiwen, W., 1996, Revised guidelines for the establisment of global chronostratigraphic standards by the International Commission on Stratigraphy (ICS): Episodes, v. 19, pp. 77-81.

Renne, P.R., Swisher, C.C., Deino, A., Karner, D.B., Owens, T.L., and DePaolo, D.J., 1998, Intercalibration of standards, absolute ages and uncertainties in ${ }^{40} \mathrm{Ar} /{ }^{39} \mathrm{Ar}$ dating: Chem. Geol., v. 145, pp. 117-152.

Rio, D., Cita, M.B., Iaccarino, S., Gelati, R., and Gnaccolini, M., 1997, Langhian, Serravallian, and Tortonian historical stratotypes, in Montanari, A., Odin, G.S., and Coccioni, R., eds., Miocene stratigraphy: An integrated approach: Devel. Palaeontol. Stratigr., v. 15, pp. 57-87.

Rio, D., Sprovieri, R., Castradori, D., and di Stefano, E., 1998, The Gelasian Stage (Upper Pliocene: A new unit of the global standard chronostratigraphic scale: Episodes, v. 21, pp. 82-87.

Sandroni, P., 1985, Rilevamento geologico al 1:10.000 e litostratigrafia di alcuni sezioni dello Schlier nel bacino marchigiano esterno e studio mineralogico e petrografica di una sezione riconstruita nell'anticlinale del Conero, Thesis, Univ. of Urbino, $188 \mathrm{pp}$

Shackleton, N.J., and Crowhurst, S., 1997, Sediment fluxes based on an orbitally tuned time scale 5 Ma to $14 \mathrm{Ma}$, Site 926: Proc. ODP, Sci. Results, v. 154, pp. 69-82.

Shackleton, N.J., Crowhurst, S.J., Weedon, G., and Laskar, J., 1999, Astronomical calibration of Oligocene-Miocene time: Roy. Soc. Lond. Philos. Trans., ser. A, v. 357, pp. 1909-1927.

Sprovieri, R., Bonomo, S., Caruso, A., di Stefano, A., di Stefano, E., Foresi, L.M., Iaccarino, S.M., Lirer, F., Mazzei, R., and Salvatorini, G., 2002, An integrated calcareous plancton biostratigraphic scheme and biochronology for the Mediterranean Middle Miocene, in Iaccarino, S., ed., Integrated stratigraphy and paleoceanography of the Mediterranean Middle Miocene: Riv. It. Paleont. Strat. v. 108, pp. 337-353, Milano.

Turco, E., Hilgen, F.J., Lourens, L.J., Shackleton, N.J., and Zachariasse, W.J., 2001, Punctuated evolution of global climate cooling during the late Middle to early Late Miocene: High-resolution planktonic foraminiferal and oxygen isotope records from the Mediterranean: Paleoceanography, v. 16 , pp. 405-423.

Turco, E., Bambini, A.M., Foresi, L.M., Iaccarino, S., Lirer, F., Mazzei, R., and Salvatorini, G., 2002, Middle Miocene high resolution calcareous plankton biostratigraphy at Site 926 (Leg 154, equat. Atlantic Ocean): paleoecological and paleobiogeographical implications: Geobios, v. 35, pp. 257-276. van Couvering, J.A., Castradori, D., Cita, M.B., Hilgen, F.J., and Rio, D., 2000, The base of the Zanclean Stage and of the Pliocene Series: Episodes, v. 23, pp. 179-187

Vervloet, C.C., 1966, Stratigraphical and micropaleontological data on the Tertiary of southern Piemont (northern Italy), Schotanus, Utrecht, 1-88 pp..

Woodburne, M.O., and Swisher, C.C., 1995, Land mammal high resolution geochronology, intercontinental overland dispersals, sea-level, climate and vicariance, in Berggren, W.A., et al., eds., Geochronology, time scales and global stratigraphic correlation, Tulsa, Oklahoma, SEPM (Society for Sedimentary Geology), pp. 335-364.

Frederik Hilgen is the present chair and past secretary of the Subcommission on Neogene Stratigraphy (SNS). His main research interest lies in the astronomical forcing of climate, in cyclostratigraphy and in constructing integrated highresolution stratigraphies and timescales.

Willem-Jan Zachariasse is the former chair and secretary of the Subcommission on Neogene Stratigraphy and has a long experience in Neogene stratigraphy with special focus on the Mediterranean. He is a planktonic foraminiferal specialist and has a great interest in paleoclimatology and paleoceanography.

Silvia Iaccarino is a renowned specialist on Neogene planktonic foraminiferal biostratigraphy and holds a life long interest in stratigraphy and paleoceanography of especially the Mediterranean Neogene.

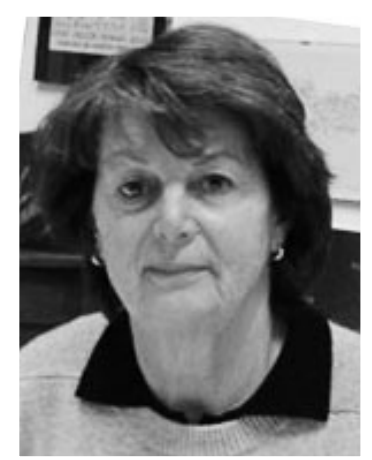

